\title{
THE RELATIONSHIP BETWEEN STRATEGY AND \\ COMPETITIVENESS IN BREWERIES - A PILOT STUDY ${ }^{1}$
}

\section{Iveta Musilová*}

\begin{abstract}
The current competitive environment is characterised by increasing uncertainty and discontinuity and the brewing industry, which is the subject of the article, is no exception. The primary objective of enterprises is to ensure competitiveness based on a sustainable competitive advantage. The choice and implementation of an appropriate strategy is an important step to sustainable success. The aim of this article is to verify the methodology regarding three basic themes of the dissertation: socio-culture environment, strategy and competitiveness. Two breweries of various sizes operating in Czech brewing were the main research sample - a small and medium-sized brewery. Mixed research methods were applied, a questionnaire and semi-structured interviews. The questionnaire was conducted with consumers to analyse the external environment. Other primary data was collected at selected breweries through semi-structured interviews and field research, followed by a search of secondary data - brewery documents including the annual accounts. Pilot research has verified that the methods chosen are suitable for determining the strategy used by the analysed breweries. The next step in the long-term horizon is to verify the link between strategy and economic performance/competitiveness.
\end{abstract}

Keywords: socio-cultural environment, business strategy, competitiveness, breweries JEL Classification: M10, M20, L10, L21

\section{Introduction}

The primary objective is the pilot testing of the methodology for dissertation. The longterm goal beyond the scope of this article is to seek a strategy-performance link. It is clear that the link between the choice of the strategy and its economic impact plays a significant role in the nature of the sector in which the organisation operates. For this reason, this pilot study is focused on organisations within a single sector, namely brewing. The reason for this choice is the long tradition and the dynamic development that has been ongoing in the last twenty years (Pulec, 2016). At the same time, multinationals, medium-sized companies and micro-companies operate in this sector thereby creating an opportunity to compare approaches to market activity for significantly different entities (Janda and Mikolasek, 2011).

Czech beer plays an important production role in the Czech Republic (CBMA, 2017b). In recent years, there has been a decline in production and the transfer of beer consumers from restaurants and pubs (gastronomic facilities) to households (Kozák, 2013).

1 This article was supported by the faculty scientific project IG632039, "Analysis of the Sector of Small and Medium-sized Enterprises in Terms of Strategy Development and Performance Measurement," and it is based on previous pilot surveys.

* University of Economics, Prague, Faculty of Management (xmusi02@vse.cz). 
The basis of competitiveness in a rapidly changing environment is an overview of the main variables in the external and internal environment (Keřkovský and Vykypěl, 2002). Knowledge of the environment will help the organisation respond to changes and, if necessary, initiate them (Morden, 1993). The change in the lifestyle of Czechs has long been noticeable when drinking beer. The change is represented by eating habits and social ties (CD-CBMA, 2018). The organisation should be able to evaluate the social and cultural factors involved. After mapping the social factors, the organisation is acquainted with the current management trends. The purpose of identifying such factors is, among other things, to adapt the previously formulated strategy (Sammut-Bonnici and Galea, 2015).

There are various sized entities in the brewing industry, as mentioned above. We can look at the size of breweries from two points of view. First, from the point of view of the volume of beer produced in hectolitres per year. Another option is to distinguish the size of the enterprises/breweries according to the number of employees as defined by CzechInvest (2019). Volume of beer produced (amount) is a professional term used to describe the overall beer production. According to the volume of beer produced, breweries are divided into mini-breweries, small, medium and large breweries. The mini-breweries range from hundreds to 10,000 hectolitres annually, the largest Czech breweries more than a million hectolitres (Pivo.cz, 2017).

The purpose of this article is to present my research in the form of fragments of my $\mathrm{Ph}$. D. study - partial pilot surveys. In the following, I submit pilot studies that were conducted to validate the methodology of the dissertation. Given the wide range of enterprise sizes within the beer industry, I focused on selected small and medium-sized breweries through the pilot research. I chose two breweries operating in the territory of the Czech Republic, namely in the Pardubice Region. These are the Municipal Brewery in Polička, a.s. located in the town of Polička and the Rychtář brewery, a.s., which is based in the town of Hlinsko v Čechách.

The common feature of both breweries is that they are located in the Pardubice Region. The selection of breweries from the same region reduced the impact of potential regional differences. Another common characteristic of breweries is their size. Breweries are medium sized with the volume of beer produced ranging from 80,000 to 120,000 hectolitres per year (designation of medium size according to according to specialized website Pivo.cz, 2017). As part of this article, small breweries are represented by the Rychtár brewery (25 employees) and medium-sized breweries represented by the Municipal Brewery in Polička (80 employees). This is a size determination based on the number of employees. The Municipal Brewery in Polička is an independent brewery while the Rychtár brewery is part of the Lobkowicz Group of Breweries. Even though, at first glance, the analysed breweries can be classified into one category according to the volume of beer produced to the medium breweries. However, the analysed breweries differ in some areas, especially in their approach to strategic management (Musilová and Dvořák, 2017; Písková, Musilová and Dvořák, 2018).

\section{Objectives of Partial Pilot Surveys}

This article contains three main themes (three main steps) that have been the basis for verifying the methodology and verifying the correct process for further research. The first part is focused on the analysis of the socio-cultural environment in brewing, especially on the current trends in beer consumption. Since this is a pilot study, it was initially 
focused on verifying the appropriate methodology and identifying potential approaches to analyse the socio-cultural environment as part of the PEST analysis. The pilot survey generally focused on beer consumption. For this purpose, a questionnaire survey was conducted among beer consumers. In order to orientate in the brewing industry and to verify consumer responses, interviews with the top management of selected groups of large breweries were conducted. The interviews were conducted for illustration, as the top management of large breweries is considered to be a specialist in the field.

Another pilot survey related to the second step in verifying the methodology for further research as part of the dissertation. This pilot study, including keywords such as strategy, competitiveness, brewing, was aimed at identifying a suitable approach and methodology to analyse the business strategy-making process and the consistency of its implementation, for example, in small and medium-sized organizations (Analysis of declared and real business strategy). The third step was to identify an approach to business competitiveness and verify any link between strategy and business competitiveness.

This is a pilot study, so the main objective is not to find out how the breweries are behaving, but whether it is possible to find this out using the selected methods. This is primarily the verification of the chosen methods and to verify that specific results can be obtained using the selected methods followed by answering the research questions. I have verified the methods for different subjects to see if the selected methods can be applied in different environments - independent brewery vs. dependent brewery as a member of a larger brewery group.

\section{Competitiveness in Terms of Environment and Strategy}

Porter and Linde (1995) in Toward and New Conception of the EnvironmentCompetitiveness Relationship present a new paradigm of international competitiveness that is dynamic, based on innovation. The basis for this research was first pulsed in The Competitive Advantage of Nations where these changes began to be addressed (Porter, 1990). Competitiveness at the sectoral level is based on superior productivity, either lower costs than the competition or the ability to offer value-added products that justify the premium price. Detailed case studies of hundreds of industries from different countries reveal international competing companies that are not the ones with the lowest inputs or companies with the largest scale, but companies with the capacity to improve and continually innovate (Porter and Linde, 1995).

The concept of competitiveness can currently be distinguished at different levels (microeconomic, macroeconomic level). However, the original understanding of this concept was related to company and company strategy. The corporate competitiveness label is then related to another concept - a competitive advantage as the ability of a firm to maintain its position on a given market (Porter, 2003). Competitiveness of regions, countries and companies is a key driver of economic growth and development. The competitiveness is increasingly attracting the interest of researchers and policymakers. Much of the work in the field of competitiveness focused on politics, institutions, society and macroeconomics although Porter reiterated that while these areas of research are necessary, they do not provide sufficient conditions for wealth creation. He argued that economic growth is the result of company productivity. The ability of these businesses to compete depends on two factors: the sophistication of their business strategies and operations, and the quality 
of the microeconomic business environment (Porter, 2004). Therefore, microeconomic competitiveness has to come to the forefront of attention (Matthee et al., 2015).

The competitiveness of the entities (economics, markets, enterprises, regions) can be considered as the composition of these items: competitiveness potential, competitive advantages, competitiveness tools and competitive position. The competitiveness of the entities is created by a system of material and non-material resources, which enable to achieve certain competitive advantages. These resources exist in specific areas of business activity such as information, production, quality management, logistics, distribution, marketing, finance, employment and others. (Kunasz, 2009). Key competencies or resolving skills are the source of complex benefits. They represent knowledge accumulated in the form of skills that can be creatively used in the whole organisation. In other words, the ability to transform resources into action. Material and intangible resources, as well as the key competencies based on them, influence competitive advantages in the market. The competitive advantage is, therefore, everything that distinguishes the products of companies or the company itself in the eyes of customers (Prahalad and Hamel, 1990; Stalk et al., 1992).

In the initial literature on the organisation, the strategy was considered or be an activity in which the owner-manager would develop an action plan that would match the opportunities and threats of the environment, the internal strengths and weaknesses and the managerial values (Andrews, 1971; Chandler, 1962). Some researchers emphasise that a key factor in sustaining growth and business development is how quickly the ownermanager can adapt and learn from the experience of acting in their environment (Milne and Thompson, 1982). There are two environments that create frameworks in which the firm operates: external environment, including suppliers, buyers, competitive strength, potential participants, interest rates, company taxation, government policies, exchange rate trends, and social, legal and political conditions; and an internal environment that consists of company resources. These features cover the range of relationships that a firm has with the environment (Gibb and Scott, 1985).

The difference between the corporate level of the strategy (What business should the organisation conduct?) and the business-level strategies (How should an organisation compete in the business?) is of vital importance. In general, a strategy consists of four components: scope, distinctiveness of competence, competitive advantage, and synergy (Hofer and Schendel, 1978). Numerous studies suggest a relationship between strategy and performance although the findings are more important in determining the importance of the strategy than determining which strategy to follow under certain circumstances (O'Farrell and Hitchens, 1988). Business performance as such is discussed in conjunction with business strategies. Business strategies are known primarily through Michael E. Porter and his generic strategies (Porter, 1985).

\section{Conclusion from the Above Theoretical Basis}

Many studies have shown that small firms are faced with management shortcomings, often undermanaged (Hjern et al., 1980), and the formulated competitive strategy is more of an idea than reality (Mikoláš, 2005). However, based on the views of some authors, small and medium-sized enterprises can apply management techniques that usually use larger size companies (Kali and RK Business Development LLC, 2002). 
The formulated strategy and its successful implementation in terms of efficiency, performance and competitiveness are not limited by the size of the enterprise but its ability to adapt quickly in relation to the environment and its individual factors and trends. In today's globalisation and competitive struggle, it is necessary for a successful business to recognize, understand and project the reality of the environment into its own business life (Mikoláš, 2005). The basic concepts of economic performance evaluation are the concept of competitiveness. Within a wider comparison, competitiveness is also considered as a reflection of success (Porter, 2004).

\section{Methods and Data}

The long-term goal is to respond to the following research questions and the task within this article as a pilot study was to find out whether it is possible to answer the formulated research questions using the selected methods. Based on the above links, the following research questions have been identified:

- What are the main reasons for changing beer consumption from consumers?

- How are breweries representatives looking at the change in beer consumption?

- How do breweries want to respond to changes in consumption? (Písková, Musilová and Dvořák, 2018).

The first research question was crucial for further research. The purpose was to clarify the main causes of the trends in beer consumption and to identify the groups of consumers affected by the changes. The second research question was directed at the representatives of selected groups of large breweries and their reaction to the results of consumer inquiries. The aim was to compare how they see changes in the beer consumption of producers, whether they identify with the results of the survey, and whether producers see any threats in the current trends or vice versa. The purpose of the third research question was to find the current or planned beer producers' reactions to current trends.

In order to find out how to grasp the second topic, the topic of the strategy and to verify the suitability of the selected methods, research questions were formulated within the long-term perspective.

- What type of business strategy according to literary research corresponds to the declared business strategy of selected breweries? How is this strategy formulated within selected breweries?

- What are the differences between the declared business strategy of breweries and the strategies they actually implement at the business level? (Musilová and Dvořák, 2017).

\subsection{Methods Used - The First Step (External Environment)}

The first step is pilot research focusing on the analysis of the environment before the strategy itself. The aim of the pilot survey is to analyse the socio-cultural environment as part of the PEST analysis. The PEST analysis is considered to be the basic method of external environmental analysis (Rothaermel, 2017). The analysis was conducted 
in the brewing industry and focused on three groups of large breweries. At the request of the respondents, their responses are anonymised and referred to as Brewery $\mathrm{A}, \mathrm{B}$ and $\mathrm{C}$.

\section{Quantitative Method - Questionnaire Survey of Consumers}

Mixed research was used to explore the socio-cultural environment. The quantitative method was represented by a semi-structured questionnaire with closed and semi-closed questions aimed at beer consumers. Data collection took two months, from mid-January to mid-March 2018, mainly through paper questionnaires distributed by random selection of respondents in different parts of the Czech Republic. The aim of the questionnaire was to identify the causes of current trends in beer consumption. The questionnaire consisted of nineteen questions. The introductory questions concerned the demographic data of respondents: age, employment, place of residence. Other questions addressed the trends in beer consumption: brand preference and beer type, beer consumption habits, and consumption habits. The key issues were Questions 18 and 19, which related to the identification of a change in beer consumption among consumers and the reason for any change. A sample of respondents can be described as representative, with representativeness being considered from several perspectives. From the point of view of education and place of residence, the sample can be considered representative, given the population of the Czech Republic (CZSO, 2014). From the point of view of the age structure, representativeness is questionable, as some age groups of respondents show more significant deviations from the percentage of the population of the Czech Republic. The older generation (the 65 and over group) is represented by only seven respondents in the survey, which is $4.04 \%$ of the number of respondents, compared to $22.26 \%$ of the population in the Czech Republic. Some distortions may be due to a larger number of the younger generation respondents (19-25 age group). This age group in research represents $26.58 \%$, compared to $8.74 \%$ within the Czech population. Based on the findings of literary research and the research itself, one can assume that younger generations of citizens have different consumer habits than older generations. Such trends include the more active leisure time of the younger generation who visit the gastronomic facilities but do not consume beer to the extent that was customary of the older generation (CZSO, 2017).

\section{Qualitative Method - Interviews with Producer Representatives}

The qualitative methods represented a semi-structured interview with the representatives of the business departments of the brewery groups surveyed. In the first part of the interviews, the aim was to find out how beer producers see current trends, or what are their predictions of trends in beer consumption in the future. In the second part, the objective was to verify whether the resulting questionnaire responses are in line with the views of the producers themselves or their experience. In the second part, the brewery's reaction to trends in beer consumption was carried out. The key question was whether breweries react to/respond to these trends or do not feel threatened. Subsequently, the data obtained was analysed, interpreted and evaluated (Písková, Musilová and Dvořák, 2018). 


\subsection{Methods Used - The Second Step (Strategy)}

The second step was pilot research on the declared strategy compared to the real business strategy of the selected breweries. The aim was to highlight the importance of setting the strategy, although the word "strategy" is something in the Czech business environment that most of the respondents "become intimidated by" immediately after the term has been pronounced. For this reason, the questions in the interviews were considered so that, if possible, the word strategy was not included at all.

Two breweries operating in the territory of the Czech Republic were selected to pilot the suitability of the methods used to answer research questions. The basis of the research was qualitative research (Figure 1), where the collection of secondary data was conducted through a local press search and the brewery for the published information. This data was then confronted with the primary data that was obtained through the qualitative poll within the selected breweries during the period from January to April 2017. The research sample of the qualitative poll: deliberate selection, targeting the top and bottom management of selected breweries - for the Municipal Brewery in Polička: The Statutory Director, procurator, production manager - brewer; for the Rychtár brewery: The Regional Sales Director, senior sales representative, production manager - brewer.

The interview was based on twenty-five questions aimed at identifying the behaviour of an organisation in terms of common strategic approaches. The aim of the introductory question was to specify the organisational structure of breweries from the point of view of the strategic level of decision-making within the brewery. Other issues related to the specificity of the breweries, which differs from the competition. Next was the topic of competitive advantage; competition; market segmentation; marketing; prices; distribution; planning, future goals and strategy. The characteristic of the breweries was to reveal which features management regards as specific and important in terms of potential competitive advantage. This is also related to the issue of importance attached to monitoring the competition.

Figure 1 | Qualitative research: scheme of data collection (methods)

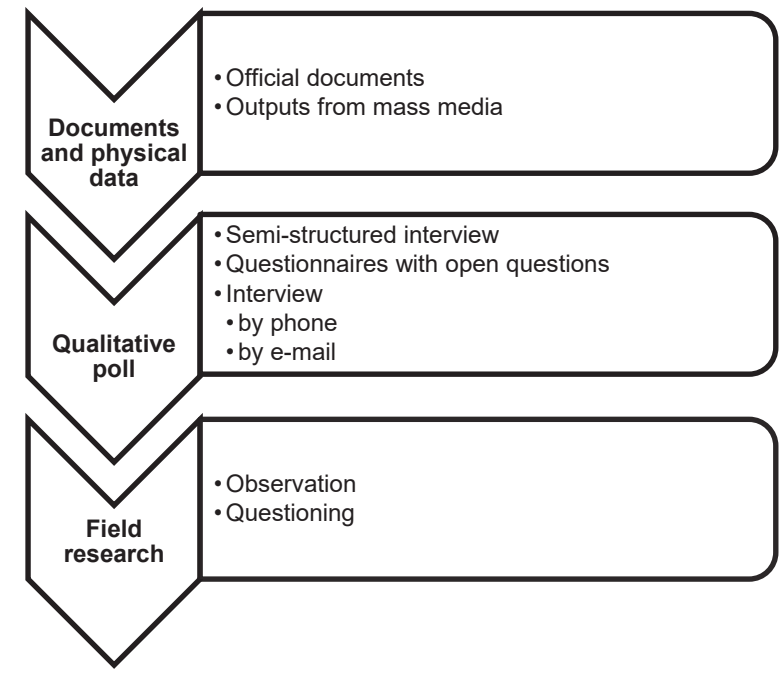

Source: Author's own research and processing 
This was a pilot verification of the suitability of the methods used. This includes the verification of the actual achievement of the strategic focus (verification of the fulfilment of the strategy) - field research was conducted. The research included price level, distribution method and level, and concurrently distributed competing brands. The research involved the on-trade (restaurants, gastronomic establishments) and off-trade market (retail chains, shops). The field research was only conducted in the cities where the breweries are located and was completed with the help of websites - the website search covered cities across the Czech Republic. The cities where the beer from selected breweries is picked up and selling. Quota selection between cities and gastronomic establishment and the random selection of gastronomic establishments and stores/shops was used (Musilová and Dvořák, 2017).

\subsection{Methods Used - The Third Step (Performance)}

Organisational performance can be measured in various ways - financial indicators, non-financial indicators, or using complex approaches (strategic, managerial approaches etc.). Profitability indicators, or returns, are among the ratios that can be included among the basic elements of financial analysis. Financial analysis is a means of analysing the financial performance of an organisation. This article only considers the return on assets indicator and shows the development over time. In general, an increasing trend or maximisation of profitability indicators is recommended.

Return on Assets (ROA), or otherwise denoted as a yield on assets, detects the resulting effect of the total embedded assets. It measures the profit with the total assets invested in the enterprise. The literature lists the calculation as a profit/asset. Assets are not reflected in their funding - by own or foreign sources. In this indicator, it is necessary to take into consideration whether to include Net Earnings (EAT) or Profit Before Tax and Interest (EBIT). For the purpose of this article, the EBIT/asset was calculated as the next step is the comparison with the competitor and the CZ-NACE classification. Therefore, the calculation is based on the EBIT item, as the literature states that to compare the analysed enterprise with other enterprises, it is appropriate to use EBIT (Dluhošová et al., 2010; Scholleová, 2012). EBIT is calculated as the economic result for the accounting period (EAT) + Income tax for ordinary activity + Interest expense (Scholleová, 2012).

In this context, the methods used to identify the link between the strategy that precedes the environmental analysis and the economic success/competitiveness, which is represented by the ROA indicator, are verified in the following. The research sample is small and medium-sized breweries. For the pilot verification of the Competitiveness Measurement Method, the calculation of the ROA indicator was chosen. The calculation of the ROA indicator included data for the Rychtár brewery and for the Municipal Brewery in Polička for the years 2010-2016 due to the availability of the necessary data for the calculation. In order to make a comparison with sectoral values, a ROA indicator for CZ-NACE beverage production was sought for each year. In order to compare breweries, competing breweries from the sector were chosen: Chodovar brewery, Krakonoš brewery and Nymburk brewery. The sources of the necessary data for the calculations were financial statements and annual reports of breweries, 2010-2016 (MJCZ, 2018; MITCZ, 2016). At this point, it is necessary to mention some constraints resulting from this fact, 
when data is not available for only one part of the section "Beverages production", namely beer production. The results may be distorted, although it is only an illustrative example and a pilot verification of the methodology.

Figure 3 shows the values of the ROA indicator in percentage terms for the period 2010-2016, for the Municipal Brewery in Polička and for the Rychtár brewery. In order to evaluate and compare the ROA values of selected breweries, the sectoral values of the ROA indicator were also used according to the CZ-NACE classification of economic activities. The limit, in this case, is that the values for Beer Production (11.05) are not disclosed although the values for the whole Beverage Production group (11) are published. Other categories: 11.01 Distillation, rectification and mixing of spirits; 11.02 Production of wine from grapes; 11.03 Manufacture of cider and other fruit wines; 11.04 Manufacture of other undistilled fermented beverages; 11.05 Manufacture of beer; 11.06 Malt production; 11.07 Manufacture of soft drinks; bottling of mineral and other bottled water (OnBusiness.cz, 2013; MFCZ, 2013). ${ }^{2}$

\section{Verification of Methods Used: Interpretation of Pilot Surveys}

Due to the limited scope of the article, only the summarised results of the partial pilot surveys are listed below.

\subsection{Analysis of the Socio-Cultural Environment in Brewing - Current Trends in Beer Consumption}

\section{Current Level of Knowledge}

Beer consumption in gastronomic establishments has decreased since 2003 with the consumption of beer in households increasing proportionally (CBMA, 2018). In 2016 , household consumption was $61 \%$, compared to $39 \%$ of beer consumption in gastronomic establishments (Johnston, 2017). Currently, the ratio is $62 \%$ for beer consumption in households and 38\% for beer consumption in gastronomic establishments. Even the "black year of Czech beer brewing" or the "beer nation can" can be found, as the preference for beer packed in sheet metal has increased, a 37\% year-on-year increase (CBMA, 2018). Some authors see the main reasons as the introduction of an anti-smoking law or EET (QSL, 2017; CTK and CT, 2017; CBMA, 2018).

Figure 2 below shows the development of the on-trade and off-trade market. Since 2009, there has been a steady increase in beer consumption in households and the difference in consumption is increasing. It is a question of whether the true cause of a decline in beer consumption in gastronomic establishments is the introduction of the EET as of 1 December 2016 (FACZ, 2018) or the smoking ban as of 31 May 2017 (MICZ, 2017), most commonly referred to as cause.

2 ROA according to CZ-NACE classification only until 2015, newer data is not available at present. Data for 2010 to 2014 is drawn from the Food Industry Panorama 2010-2014 (MACZ, 2015). The year 2015 was calculated according to the documents of the Ministry of Industry and Trade (MITCZ, 2016). 


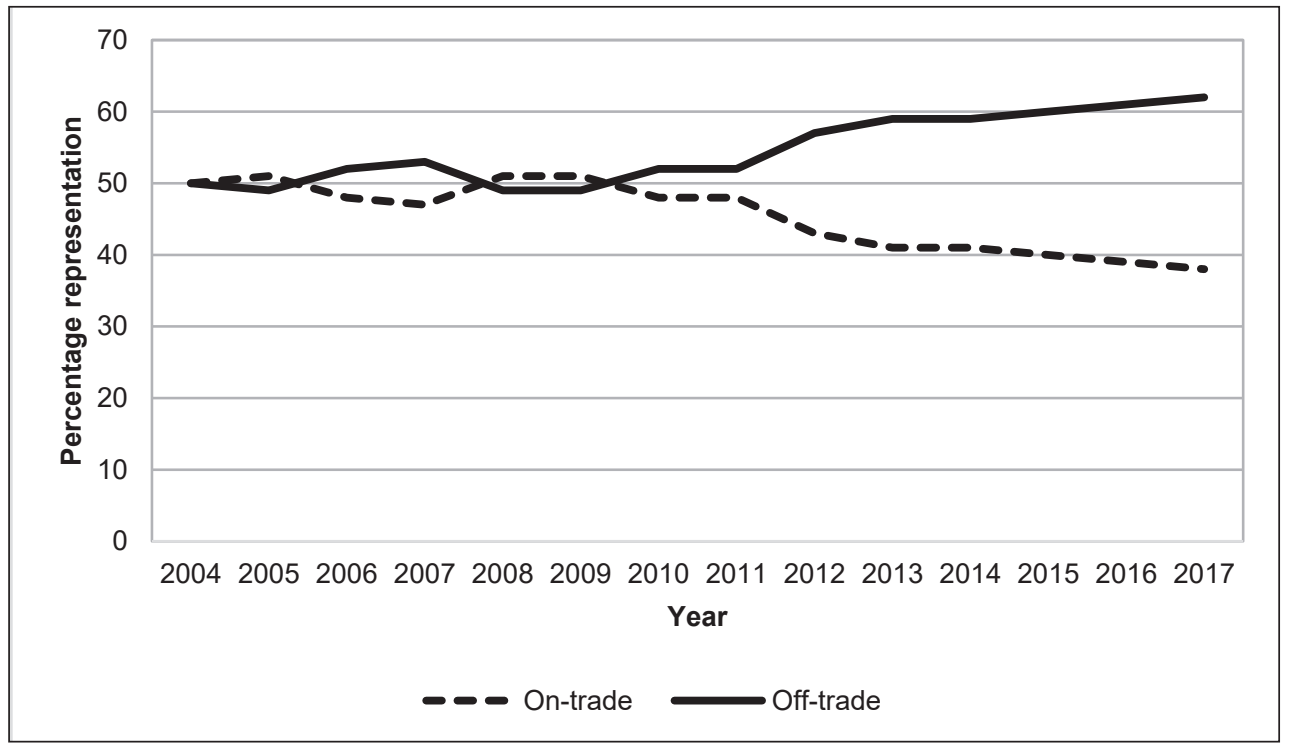

Source: Author's own processing based on data from (CBMA and Šámal, 2015; CBMA, 2017a; CBMA, 2018)

\section{Resulting Reasons for Change/Trends in Beer Consumption View of Beer Consumers}

Questionnaires in paper form were completed by 166 respondents, men and women equally, with men representing almost 56\% of respondents. Most respondents (127 respondents) replied that there had been no change in them over a ten-year period. Only four respondents answered that they had switched from home to a restaurant. The remaining 35 respondents said they had switched from a restaurant to home for their beer consumption.

\section{Reaction to Trends by Breweries}

Representatives of selected breweries follow the trends and compile their current statistics. Breweries look slightly different at the impact of the trends, where Brewery A sees the economic impact of trends as a threat. However, it tries to prepare and respond to it in the form of cooperation with gastronomic facilities - map consumer demand and then satisfy it. Brewery B perceives current trends as an opportunity for discovering gaps in the beer market, which can then be resolved by taking the new gap. Brewery $\mathrm{C}$ perceives the current situation as an opportunity for new discoveries to target a different consumer segment.

\section{Conclusion of the Pilot Survey}

An interesting conclusion to the pilot survey is that most consumers did not notice any change in beer consumption and only a small number said they had moved their consumption, the main reason being the smoking ban. On the contrary, producers have 
noted this and are trying to react to it. There is a certain mismatch in the viewpoint of consumers and producers, which can be explained by the greater interest in understanding the changes in the environment by producers. There were no significant differences in opinions or reactions between the responses of individual breweries. The main difference is that Brewers $\mathrm{B}$ and $\mathrm{C}$ are viewing the trends as an opportunity for improvement while Brewery A sees the change as a threat (Písková, Musilová and Dvořák, 2018).

\subsection{Analysis of Declared and Real Business Strategy}

In most cases, the ranking was based on two benchmarks: quality and price. The production process (the traditional method of production), which both breweries use, i.e. the brewing of each beer separately and the use of lager tanks, not CK tanks. The quality of the raw materials used for production (Morávek, 2013), which all breweries have the same, is distinguished by their quality differences (differentiation strategy).

Types of Business Strategies - Both selected breweries use the strategy of differentiation according to Porter's Generic strategies, namely the focus on differentiated products with a broad target. Differentiation is achieved by competitive advantage and a broad target is for customers over 18 years of age in the case of beer. This is concentrated on customers from different parts of the Czech Republic and is aimed at a broad target.

Above all, differentiation is achieved by the previously mentioned traditional production, through which high-quality beer is achieved. Traditional production uses traditional techniques using modern technology. Other competing breweries produce their products using modern methods that consist of the production of strong beer, and subsequently, the beer is diluted with water. In this way, predetermined grades of beer are achieved. In the case of the Municipal Brewery in Polička, there is another competitive advantage of non-creditworthy farming; their own water well and a well where the quality of water mostly contributes to the quality of the final product - beer; nonstop brewery shop. The competitive advantage of the Rychtár brewery is primarily the raw material used in the production of beer - the hops, which are used in their natural form. This form of hops is already used by the last two breweries in the Czech Republic (Musilová, 2017).

Studies - In the case of selected breweries and their strategic management, it is possible to agree with a study which found that small organisations prefer a formally defined competitive advantage in their strategic plan (Dvořák et al., 2013). The Rychtár brewery (according to the number of employees it is designated as a small enterprise) emphasises its competitive advantage not only within the brewery but above all outside - see its website, brochures etc. - and formalises these as part of a strategic plan. The Municipal Brewery in Polička (according to the number of employees it falls into the category of medium-sized enterprises) has competitive advantages defined above all in the awareness of brewery employees, not in the strategic plan. This is not entirely consistent with the findings in the study, where medium-sized organisations had a formally defined competitive advantage although this was not strict. The research further showed that differentiation strategies are preferred by organisations with foreign owners (the Rychtár brewery) and by domestic organisations (the Municipal Brewery in Polička) (Dvořák et al., 2013). 


\section{Conclusion of the Pilot Survey}

Both breweries focus on the specific taste of their production and quality. For the reasons mentioned above, the direction of the breweries analysed can be classified as a differentiation strategy (an effort to differentiate the product - the specificity of production by competitive advantage) according to Porter's generic strategies. Formally, the strategy at the Municipal Brewery in Polička is not defined; the Rychtár brewery has a formally declared strategy only at the group level (Musilová and Dvořák, 2017).

\subsection{Return on Assets Representing Breweries Performance}

The third successive step was to find a suitable method to measure the performance/ competitiveness of selected breweries. For the pilot verification, a partial indicator of the financial analysis was chosen, namely the return on assets (ROA).

In 2010, the history of Czech brewing was not written in stone, as is evident from Figure 3 below. The decline was also due to an increase in excise duty in January 2010. The data for the whole beer market has shown that beer consumption associated with the volume of beer produced in 2010 dropped by a whole $12 \%$ (BERNARD, 2010). Subsequently, the years 2010-2012, the post-crisis years, were complex for the whole brewing industry (Němec, 2018).

According to Figure 3 below, the ROA of the Municipal Brewery in Polička has tended to grow since 2011, which is a desirable trend in the case of profitability. Between 2014 and 2015, there was a decline, but then it rose again year-on-year (2015-2016) to the maximum value within the analysed period of $2010-2016$, up to $16.95 \%$. However, the Rychtár brewery and the ROA value varied in "diametrically" different values for the period 2012-2016, and almost throughout the surveyed period the ROA had a decreasing trend. Even for the whole ROA period analysed, the Rychtár brewery ranged below the ROA for the beverage industry according to the CZ-NACE classification.

Figure 3 | ROA indicator values for analysed breweries compared to industry values

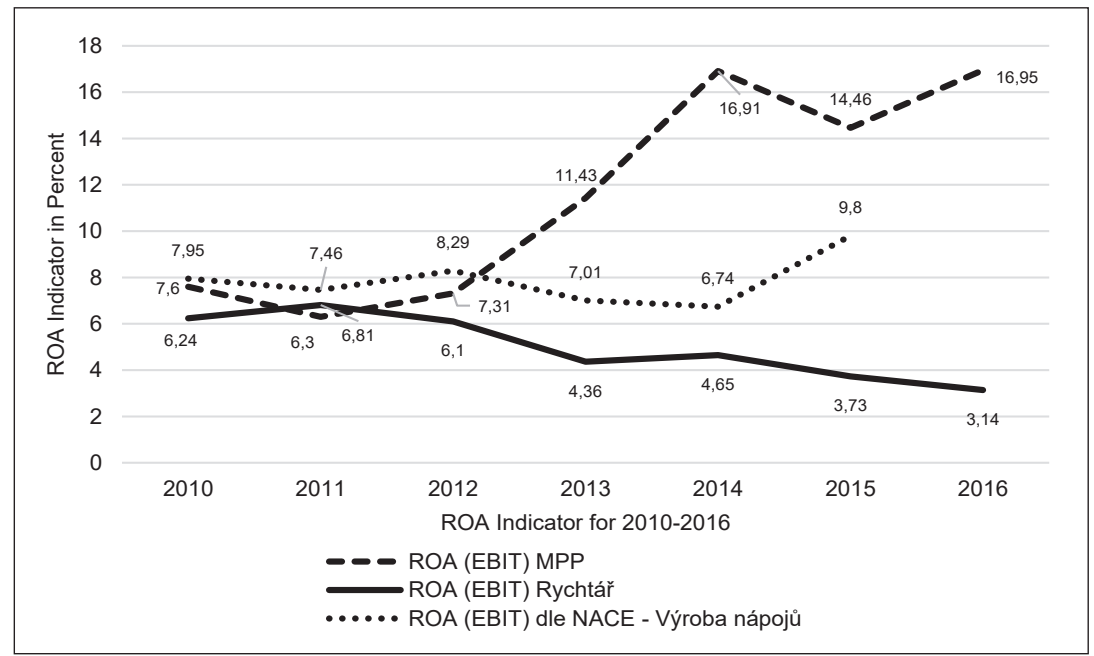

Note: Sectoral ROA ratios are represented by CZ-NACE (Beverage production); MPP stands for the Municipal Brewery in Polička..

Source: Author's own processing based on data from (MJCZ, 2018) and (MITCZ, 2016). 
The resulting ROA values of the analysed breweries are displayed to complement the ROA of competing breweries of a similar size in the attached Figure 4. The Municipal Brewery in Polička and the brewery competition stand well with regard to the analysed ROA. The Rychtár brewery is slightly worse although competing breweries showed even more unsatisfactory results.

\section{Discussion}

Further studies on generic strategy and organisation performance have put forward a concrete finding that the diversification strategy is preferred by a larger number of businesses although there is no significant link to the size of the business. There is also no significant link between the strategy type (a Generic strategy choice) and business performance based on the comparison of its ROA coefficient of the organisation (Dvořák et al., 2013). However, this research was conducted across a wide range of organisations within the industry in the Czech Republic, with different industries being represented by NACE categorisation. This fact is a limitation of the research results with respect to the subsequent calculation of ROA and the comparison of organisations based on the calculated ROA within the different industries of the Czech Republic.

The assumption is that the size of the organisation and mainly the ability to quickly adapt to the environment and its individual factors and trends plays a role in formulating the strategy and its successful implementation in the context of competitiveness. An approach to analysing the competition and responding to current trends within a particular environment is undoubtedly part of formulating, and consequently, implementing an appropriate strategy.

The analysed breweries can be included among Porter's Generic Differentiation strategy, as it is a competitive advantage for selected breweries, thus differentiating itself from the competition to gain a potential or maintain an existing customer. In this chapter, it is advisable to discuss the decision in the Rychtár brewery as part of the Lobkowicz Group of Breweries. The question of influencing decision-making by the Lobkowicz Group of Breweries was also included in the interviews. The decisionmaking process and the degree of influence were verified in this way. The Rychtár brewery is headed by the Executive Director based in Černá Hora. The Executive Director defines strategies and management cannot change them. The top management in Prague or the business directors of individual areas may make comments and recommendations to the Executive Director, and on this basis, decisions are made; decision making is dependent.

The question is whether the dependence or independence of the brewery plays a role. Two different breweries were deliberately chosen in this respect to verify the functioning of the selected methods. Another possible question arises as to whether it is important who created a specific strategy in a particular company. This is not important for the pilot verification. The important issue is whether the strategy is declared, whether it is implemented and how it actually works. It is also necessary to take into account the degree of identification with employees with a defined strategy. 


\section{Conclusion}

The three chosen themes intertwine and affect each other. The strategy should be preceded by an analysis of the external environment. After analysing the external environment, we are able to identify the influencing factors and current trends, and we can respond to this situation with the appropriate strategy. From the appropriately formulated strategy, the next main topic is business performance and competitiveness. Therefore, there is a particular sequence and continuity among the chosen themes.

This is a pilot study, so the main objective was not to find out how a brewery or the environment behaves, but if the chosen methods will allow this to be determined. The chosen methodology is validated on very different subjects in order to find out and verify that it works in different environments. Therefore, the evaluation is that it is possible to obtain interpretable data and that it is a good basis for further work.

External Environment - From the data obtained, it is not clear what is the true cause of current trends. The pilot survey has been able to describe current trends in beer consumption although the true "historical“ cause remains unclear. The lessons learned from the analysis provide the basis for further research in order to predict trends in the brewing industry and their impact on the sector. Appropriate ways can be to obtain more respondents and a separate analysis of each age group (Písková, Musilová and Dvořák, 2018).

Strategy - Using the applied methods, it was possible to show the basic approach taken by the analysed companies to the issues of strategy development. Background searches and semi-structured interviews have clearly demonstrated access to selected breweries to create a business strategy. In the case of the Rychtár brewery, this approach is clearly more systematic, which is probably the result of being part of a larger brewing group. In the case of the Municipal Brewery in Polička, intuition plays a bigger role, but in terms of differentiation, both breweries are similar. Given that only two breweries were analysed, the conclusions obtained cannot be generalised to the sector or its segment. Nonetheless, the methodological approach has proven to be suitable for further research into the behaviour of smaller breweries (Musilová and Dvořák, 2017).

Performance (ROA) - Put simply, it can be estimated that the Municipal Brewery in Polička, which manages according to an intuitively declared strategy, moved in very favourable values of asset profitability, especially in 2016. On the contrary, the Rychtár brewery, which has a formally declared strategy in a strategic document, moved in unsatisfactory ROA values throughout the analysed period. Thus, in a simplified way, it can be summarised that in this case the level of strategy formalisation or competitive advantage, negatively affects the course of ROA. This was only a demonstrative example to verify the method and to outline how I would like to continue my research. I see the potential in the combination of strategy and performance - the connection between performance/competitiveness and a generic strategy choice. I would like to extend my further research to a corresponding number of small and mediumsized organisations. From the above research limitation, I would like to focus on organisations from only one sector - brewing, which will eliminate the intersectoral differences. 


\section{Acknowledgements}

The pilot survey Analysis of Declared and Real Business Strategy - A Pilot Survey is the output of the faculty scientific project IG632096, Analysis of the Design and Use of Business Strategies in Selected Branches in the Czech Republic. It is directly based on the cooperation in the preparation of the diploma thesis, which was connected to this project and represents part of the results of this diploma thesis: Bc. Iveta Musilová, Analysis of the declared strategy of selected breweries in terms of its implementation, April 2017, Faculty of Management, University of Economics. The pilot survey Analysis of the Socio-cultural Environment in Brewing - The Current Trends in Beer Consumption - A Pilot Survey is based on the cooperation in the preparation of the diploma thesis and represents part of the results of the diploma thesis Bc. Jana Písková, Analysis of selected parts of the external environment in brewing - Analysis of the socio-cultural environment and analysis of the main trends in the sector with regard to its changes in the global environment, April 2018, Faculty of Management, University of Economics.

\section{References}

Andrews, K. R. (1971). The Concept of Corporate Strategy. Dow Jones-Irwin, Homewood, III.

CTK (Czech News Agency), and CT (Czech Television), (2017). Česko se stává zemí plechovkového piva. Čepované pivo je na ústupu [The Czech Republic Becomes a Land of Tin Can. Draft Beer Is on the Decline.]. [online] ceskatelevize.cz. Available at: http://www.ceskatelevize.cz/ct24/ekonomika/2274979-cesko-se-stava-zemiplechovkoveho-piva-cepovane-pivo-je-na-ustupu [Accessed 8 Apr. 2018]

Czechlnvest (2019). Definice malého a středního podnikatele [Definition of Small and Mediumsized Businesses]. [online] czechinvest.org. Available at: https://www.czechinvest.org/cz/Sluzby-pro-male-a-stredni-podnikatele/Chcete-dotace/ OPPI/Radce/Definice-maleho-a-stredniho-podnikatele [Accessed 8 Jan. 2019]

CD-CBMA (Czech Drinks and Czech Breweries and Malts Association), (2018). Životní styl Čechů se sice mění, ale pivo jim dál chutná [The Lifestyle of the Czechs Changes but the Beer Still Tastes Them]. [online] ceskenapoje.cz. Available at:

http://www.ceskenapoje.cz//beer/zivotni-styl-cechu-se-sice-meni-ale-pivo-jim-dalchutna.html [Accessed 8 Apr. 2018]

CBMA (Czech Breweries and Malts Association) and Šámal, F. (2015). Zpráva o stavu českého pivovarství a sladařství za rok 2015 [Report on the State of Czech Brewing and Malting for 2015]. [online] pivni.info Available at:

http://pivni.info/down/2016_hospodarske-vysledky-oboru-za-2015.pdf [Accessed 8 Apr. 2018]

CBMA (2017a). Rekordní výstav piva v roce 2016 podpořen exportem i vyšší spotřebou na tuzemském trhu [The Record Annual Beer Production in 2016 Is Backed by Export and Higher Consumption on the Domestic Market]. [online] ceske-pivo.cz. Available at: http://ceske-pivo.cz/tz/rekordni-vystav-piva-v-roce-2016-podporen-exportem-i-vyssispotrebou-na-tuzemskem-trhu [Accessed 13 Apr. 2018]

CBMA (2017b). České pivo [Czech Beer]. [online] ceske-pivo.cz. Available at: http://ceske-pivo.cz/ceske-pivo [Accessed 4 Nov. 2017]

CBMA (2018). Export vykrývá ztráty pivovarnictví za loňský rok [The Export Concludes Brewing Losses for Last Year]. [online] ceske-pivo.cz. Available at: http://ceske-pivo.cz/export-vykryva-ztraty-pivovarnictvi-za-lonsky-rok [Accessed 30 Apr. 2018] 
CZSO (Czech Statistical Office), (2014). Úroveň vzdělání obyvatelstva podle výsledků sčítání lidu [The Level of Education of the Population According to the Census Results]. [online] czso.cz. Available at: https://www.czso.cz/documents/10180/20536250/17023214. pdf/7545a15a-8565-458b-b4e3-e8bf43255b12?version=1.1 [Accessed 14 Mar. 2018]

CZSO (2017). Věkové složení obyvatelstva - 2016 [Age Structure of the Population]. [online] czso.cz. Available at:

https://www.czso.cz/csu/czso/vekove-slozeni-obyvatelstva-2016 [Accessed 14 Mar. 2018]

Dluhošová, D. et al. (2010). Finanční ř́zení a rozhodování podniku: Analýza, investování, oceňování, riziko, flexibilita (3rd ed.) [Financial Management and Business Decisionmaking: Analysis, Investment, Valuation, Risk, Flexibility]. Prague: EKOPRESS.

Dvořák, J. et al. (2013). Generic Strategies and Organizational Performance: Evidence from Czech Business Environment. International Conference on Business Administration: Mathematics and Computers in Contemporary Science. [online] wseas.us. Available at: http://www.wseas.us/e-library/conferences/2013/Milan/ICMA/ICMA-11.pdf [Accessed 29 Sept. 2018]

BERNARD (2010). Nebývalý pokles pivovarnického trhu [Unprecedented Decline in the Brewing Market]. [online] bernard.cz. Available at:

https://www.bernard.cz/srv/www/content/pub/cs/pribeh/tiskove-zpravy/113.html [Accessed 29 Sept. 2018]

FACZ (Financial Administration, Czech Republic), (2018). E-tržby - Elektronická evidence tržeb [E-sales - Electronic Sales Records]. [online] etrzby.cz. Available at: http://www.etrzby.cz [Accessed 8 Apr. 2018]

Gibb, A., and Scott, M. (1985). Strategic Awareness, Personal Commitment and the Process of Planning in the Small Business. Journal of Management Studies, 22(6), pp. 597-631. https://doi.org/10.1111/j.1467-6486.1985.tb00014.x

Hjern, R. et al., (1980). Helping Small Firms Grow [discussion paper series]. International Institute of Management, Berlin.

Hofer, C. W., and Schendel, D. (1978). Strategy Formulation: Analytical Concepts. Saint Paul (Conn.): West Publishing Co.

Chandler Jr., A. D. (1962). Strategy and Structure: Chapters in the History of the American Industrial Enterprise. Cambridge, MA: MIT Press.

Janda, K., and Mikolasek, J. (2011). Success in Economic Transformation of the Czech Beer Industry and Its Social Costs and Benefits. Transformations in Business and Economics, 10(3), pp. 117-137.

Johnston, R. (2017). Czech Beer Production and Consumption Increases. [online] prague.tv. Available at: https://prague.tv/en/s72/Directory/c203-Restaurant-Guide-Prague/n9294Czech-beer-production-and-consumption-increases [Accessed 8 Apr. 2018]

Kali, B. and RK Business Development LLC, (2002). Strategic Performance Measurement. [online] corp21.com. Available at: http://www.corp21.com/download/PerformanceMgmt030827.pdf [Accessed 8 Apr. 2018]

Keřkovský, M., and Vykypěl, O. (2002). Strategické řizení. Teorie pro praxi [Strategic Management. Theory for Practice]. Prague: C.H. Beck.

Kozák, V. (2013). Analysis of Reasons for Beer Consumption Drop in the Czech Republic. Marketing and Business. Economics and Management, 16(3), pp. 130-138.

Kunasz, M. (2009). Entrepreneurship - Microeconomic Determinant of the Competitiveness of Entities. Economics \& Sociology, 2(1), pp. 37-46. 
Matthee, M. et al. (2015). Microeconomic Competitiveness and Post Conflict Reconstruction: Firm-Level Evidence from Zimbabwe. International Business \& Economics Research Journal, 14(3), pp. 525-536. https://doi.org/10.19030/iber.v14i3.9214

Mikoláš, Z. (2005). Jak zvýšit konkurenceschopnost podniku: Konkurenční dynamika a potenciál podnikání [How to Increase Business Competitiveness: Competitive Potential and Business Dynamics]. Prague: Grada Publishing.

Milne, T., and Thompson, M. (1982). The Infant Business Development Process [Management Studies Working paper no. 2]. University of Glasgow, Glasgow.

Morávek, D. (2013). Boom minipivovarů [Microbrewery Boom]. [online] euro.cz Available at: https://www.euro.cz/byznys/boom-minipivovaru-958983 [Accessed 8 Apr. 2018]

Morden, T. (1993). Business Strategy and Planning: Text and Cases. London: McGraw-Hill.

Musilová, I. (2017). Analýza deklarované strategie vybraných pivovarů z hlediska její realizace [Analysis of the Declared Strategy of Selected Breweries from the Point of View of its Realization]. [Diploma thesis]. Prague: University of Economics, Faculty of Management.

Musilová, I., and Dvořák, J. (2017). Analýza deklarované a skutečné "business" strategie pilotní průzkum [Analysis of Declared and Real "Business" Strategy - Pilot Survey]. In S. Rojík and J. Závodný Pospíšil, eds., Proceedings of 9th Annual International Scientific Conference COMPETITION (pp. 590-599). [CD-ROM, online]. Jihlava, 18th June 2017. Jihlava: College of Polytechnics. Available at: https://konference.vspj.cz/ download?hash=ba70da5ca49bb6c39b4d30f3ff5515cbbdce1b71 [Accessed 4 Apr. 2018]

MACZ (Ministry of Agriculture of the Czech Republic), (2015). Panorama potravinářského průmyslu 2014 [Panorama of the Food Industry 2014]. [online] eagri.cz. Available at: http://eagri.cz/public/web/mze/potraviny/publikace-a-dokumenty/panoramapotravinarskeho-prumyslu/panorama-potravinarskeho-prumyslu-2014.html [Accessed 29 Sept. 2018]

MICZ (Ministry of the Interior of the Czech Republic), (2017). 65/2017 Zákon o ochraně zdraví před škodlivými účinky návykových látek [Amendment to Act No. 65/2017 Coll., On the Protection of Health from Harmful Effects of Addictive Substances]. [online] mvcr.cz. Available at: https://aplikace.mvcr.cz/sbirka-zakonu/SearchResult. aspx?q=2017\&typeLaw=zakon\&what=Rok\&stranka=16 [Accessed 8 Apr. 2018]

MITCZ (Ministry of Industry and Trade of the Czech Republic), (2016). Finanční analýza podnikové sféry za 1. - 4. čtvrtletí 2015 [Financial Analysis of the Corporate Sector for the 1st - 4th quarter 2015]. [online] mpo.cz. Available at:

https://www.mpo.cz/cz/rozcestnik/analyticke-materialy-a-statistiky/analyticke-materialy/ financni-analyza-podnikove-sfery-za-1--_-4--ctvrtleti-2015--221221/ [Accessed 29 Sept. 2018]

MFCZ (Ministry of Finance of the Czech Republic), (2013). Klasifikace ekonomických činností (CZ-NACE) na ČSÚ [Classification of Economic Activities (CZ-NACE) at CZSO]. [online] $m f c r$. cz. Available at: http://wwwinfo.mfcr.cz/ares/nace/ares_nace.html.cz [Accessed 29 Sept. 2018]

MJCZ (Ministry of Justice of the Czech Republic), (2018). Veřejný rejstřík a Sbírka listin. [Public Register and Collection of Documents]. [online] or.justice.cz. Available at: https://or.justice.cz/ias/ui/rejstrik [Accessed 29 Sept. 2018]

Němec, J. (2018). Minipivovary pod pantoflem úřadů [Microbreweries Kept on a Tight Leash by the Authorities]. [online] ekonom.ihned.cz. Available: https://ekonom.ihned.cz/c166180880-minipivovary-pod-pantoflem-uradu [Accessed 29 Sept. 2018] 
O'Farrell, P. N., and Hitchens, D. (1988). Alternative Theories of Small-Firm Growth: A Critical Review. Environment and Planning A: Economy and Space, 20(10), pp. 1365-1383. https://doi.org/10.1068/a201365

OnBusiness.Cz, (2013). OKEČ, NACE, CZ-NACE: Vyznejte se v klasifikaci ekonomických činností. [OKEČ, NACE, CZ-NACE: Become Skilled in the Classification of Economic Activities]. [online] onbusiness.cz. Available at: http://onbusiness.cz/okec-nace-cznace-tabulkaklasifikace-ekonomickych-cinnosti-169 [Accessed 29 Sept. 2018]

Písková, J., Musilová, I., and Dvořák, J. (2018). Analýza socio-kulturního prostředí v pivovarnictví - Současné trendy v konzumaci piva - pilotní průzkum [Analysis of Socio-cultural Environment in Brewing - Current Trends in Beer Consumption - Pilot Survey]. In R. Fiala and J. Závodný Pospíšil, eds., Proceedings of 10th Annual International Scientific Conference COMPETITION (pp. 334-344). [online]. Jihlava, 17th May - 18th May 2018. Jihlava: College of Polytechnics. Available at: https://konference.vspj.cz/ download?hash=13c37c0a4135711ba1f51b351dc798e53424db78 [Accessed 20 Jun. 2018]

Pivo.cz (2017). Pivovary a minipivovary v Česku [Breweries and Microbreweries in the Czech Republic]. [online] pivo.cz Available at: https://pivo.cz/pivovary-a-minipivovary-v-cesku [Accessed 29 Sept. 2018]

Porter, M. E. (1985). The Competitive Advantage: Creating and Sustaining Superior Performance. New York: Free Press.

Porter, M. E. (1990). The Competitive Advantage of Nations. Harvard Business Review, 68(2), pp. 73-93.

Porter, M. E., and van der Linde, C. (1995). Toward a New Conception of the EnvironmentCompetitiveness Relationship. Journal of Economic Perspectives, 9(4), pp. 97-118. https://doi.org/10.1257/jep.9.4.97

Porter, M. E. (2003). The Economic Performance of Regions. Regional Studies, 37 (6/7), pp. 549-578. https://doi.org/10.1080/0034340032000108688

Porter, M. E. (2004). Building the Microeconomic Foundations of Prosperity: Findings from the Business Competitiveness Index. In M. E. Porter, K. Schwab and X. Sala-i-Martin, eds., The Global Competitiveness Report 2003-2004 (pp. 29-56). Oxford, UK: Oxford University Press.

Prahalad, C. K., and Hamel, G. (1990). The Core Competence of the Corporation. Harvard Business Review, 68(3), pp. 79-91.

Pulec, J. (2016). Integration of the Czech Brewing Industry into Global Production Networks. Acta Universitatis Carolinae, Geographica, 51(1), pp. 47-59. https://doi.org/10.14712/23361980.2016.5

QSL (2017). Spotřeba piva v pohostinství klesá, v domácnostech naopak roste [Beer Consumption in the Hospitality Declines, conversely, in Households It Grows]. [online] iQSL.cz. Available at: http://www.iqsl.cz/spotreba-piva-v-pohostinstvi-klesa-vdomacnostech-naopak-roste [Accessed 8 Apr. 2018]

Rothaermel, F. T. (2017). Strategic Management. New York: McGraw-Hill Education.

Sammut-Bonnici, T., and Galea, D. (2015). PEST Analysis. Wiley Encyclopaedia of Management, 12. https://doi.org/10.1002/9781118785317.weom120113.

Scholleová, H. (2012). Ekonomické a finanční rízení pro neekonomy (2nd ed.) [Economic and Financial Management for Non-Economists]. Prague: Grada Publishing.

Stalk, G. et al. (1992). Competing on Capabilities: The New Rules of Corporate Strategy. Harvard Business Review, 70(2), pp. 57-69. 


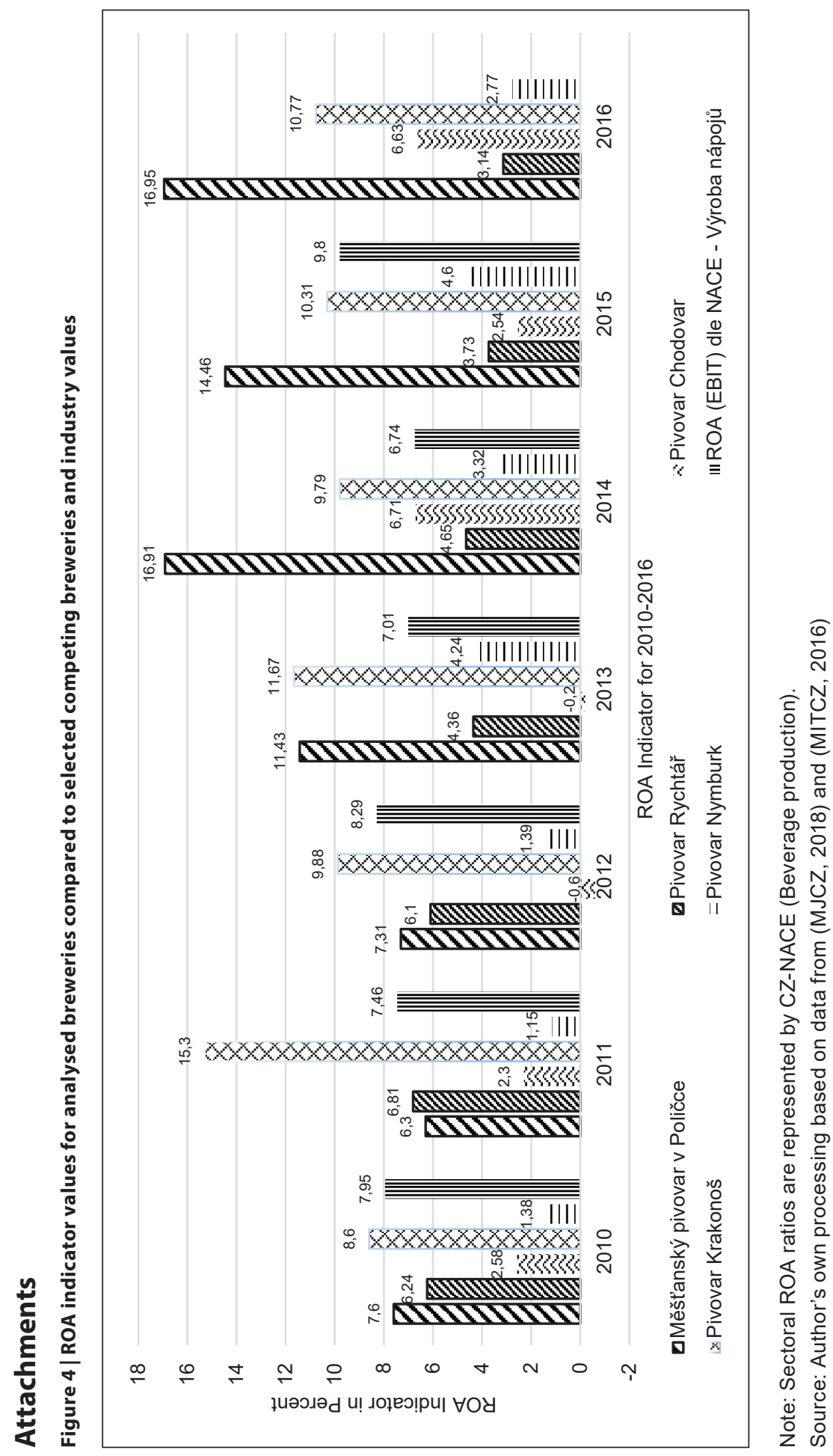

